\title{
Credit Risk Elements for Small and Medium-Sized Enterprises: The Case of Spain
}

Submitted 11/03/21, 1st revision 14/04/21, 2nd revision 30/04/21, accepted 20/05/21

\author{
Alaitz Mendizabal ${ }^{1}$, Aitziber Olasolo ${ }^{2}$, Marian Zubia $^{3}$, Ana Blanco $^{4}$
}

\begin{abstract}
:
Purpose: The aim of this paper is, firstly, to identify the elements banks consider when assessing the credit risk of SMEs and, subsequently, to propose actions aimed at helping them to transmit reliable information on their credit quality.

Design/methodology/approach: In this study, a dual methodology was used, both of which are qualitative and complementary, at first, in-depth interviews with specialists and, subsequently, the Delphi method. A panel of expert representatives of the Spanish banking system were selected. Then, firstly, personal interviews were carried out. Subsequently, once the information has been collected and analysed, the Delphi method was applied.

Findings: Results show that the experts unanimously consider that SMEs need to provide a balance sheet and profit and loss account. In addition, there is a broad consensus in the assessment of the importance of the audit report and corporation tax, while the documents relating to VAT settlement and the declaration of transactions with third parties is also important. Depending on the profile of the experts, it can be seen that, in general, the importance attached to the request for this type of documentation by the group of risk analysts is slightly lower than in the group of branch managers.

Practical implications: Therefore, the contribution of this paper to the existing literature consists, on the one hand, of the application of a different approach, from the banks' perspective, and, on the other hand, of the identification of the type of information that banks consider essential when analysing SMEs' applications for financing, as well as providing recommendations to SMEs to improve the conditions for access to bank financing.

Originality value: The proposed methodology would improve the flow of information between companies and institutions and help to reduce the problem of information opacity, which, can condition access to bank financing.
\end{abstract}

\footnotetext{
${ }^{1}$ Dpt. Financial Economics II alaitz.mendizabal@ehu.eus

University of the Basque Country UPV/EHU, Oñati Plaza n ${ }^{\circ} 1 \mid 20018$ DONOSTIA, Spain. www.ehu.eus

${ }^{2}$ Dpt. Financial Economics II aitziber.olasolo@ehu.eus

University of the Basque Country UPV/EHU, Oñati Plaza $n^{\circ} 1 \mid 20018$ DONOSTIA, Spain. www.ehu.eus

${ }^{3}$ Dpt. Quantitative Methods marian.zubia@ehu.eus

University of the Basque Country UPV/EHU, Oñati Plaza $n^{\circ} 1 \mid 20018$ DONOSTIA, Spain. www.ehu.eus

${ }^{4}$ Institute of Applied Business Economics, ana.blancom@ehu.eus

University of the Basque Country UPV/EHU, Avda. Lehendakari Aguirre, $n^{\circ} 83 \mid 48015$

BILBAO, Spain.
} 
Keywords: SMEs, credit risk, access to financing.

JEL codes: G0, G2, G3.

Paper Type: Research article.

\section{Introduction 5}

Small and medium-sized enterprises (SMEs) play an important role in the economy ${ }^{6}$, both in terms of their contribution to employment generation and their productivity. Moreover, SMEs now compete in a world where they need to be globally competitive in order to face the challenges of the future. Innovation, internationalisation and collaboration are key factors for survival in today's everchanging environment. These competitive business behaviours force companies to carry out processes and actions that require investments of varying degrees of significance. It is at this point where one of the biggest problems of SMEs comes to the fore, access to external financing (Lehman and Neuberger, 2001), with bank financing being the source to which these companies turn predominantly (Berger and Udell, 1998; Selva and Giner, 1999; Montoriol, 2006).

The problems of access to bank financing for SMEs are mainly due to information asymmetries in the credit markets. These asymmetries stem, among other factors, from SMEs' limited availability of information on their financial situation, which results in information opacity towards the outside world. Consequently, banks find it difficult to adequately assess the credit risk of these companies (Berger and Udell, 1995), conditioning the decision to grant bank financing (Cardone et al., 2005). Banks, for their part, can reduce the information opacity of SMEs by obtaining more and better information on their credit risk. In this context, the banking relationship could be considered a very appropriate communication channel, reducing information opacity as the information is more complete, transparent and easy to verify.

However, the problem of information opacity is also detected on the banks' side, specifically in the criteria used for credit risk rating. The procedure for SME credit risk rating and measurement by banks is not public.

\footnotetext{
${ }^{5}$ This work was carried out within the framework of the University-Business-Society Research Project 2019 (US19/16) of the University of the Basque Country, with the collaboration of the FESIDE Foundation. It contains the preliminary results of the Delphi process on the credit risk rating of SMEs and its consequent effect on access to bank financing. In sharing this information, we would like to thank all the experts who participated in this phase and made this study possible with their valuable contributions. We appreciate their time and hope that the results obtained will be of interest to you.

${ }^{6}$ According to the General Secretariat for Industry and Small and Medium-sized Enterprises (Ministry of Industry, Trade and Tourism), as of December 2020, there were 2,884,099 companies in Spain, of which 2,879,343 (99.9\%) were SMEs.
} 
In view of the above, this paper aims, firstly, to identify the elements banks consider when assessing the credit risk of SMEs, and then to propose actions to help SMEs transmit a greater quantity and better reliable information on their credit quality to banks. This would improve the channelling of information from SMEs to banks, with a positive effect on credit risk assessment. This would result in better allocation of financial resources in the credit market, which in turn would contribute to economic growth (Rajan and Zingales, 1998).

Therefore, the contribution of this paper to the existing literature consists, on the one hand, of the application of a different approach, from the banks' perspective, and, on the other hand, of the identification of the type of information that banks consider essential when analysing SMEs' applications for financing, as well as providing recommendations to SMEs to improve the conditions for access to bank financing.

The paper is structured in six sections. After the introduction, the second section identifies the theoretical foundations regarding the problems of information asymmetry in credit markets and its effect on SMEs' access to bank financing. The third section analyses the credit risk rating of SMEs, including the elements considered by banks. Then, in the fourth section, the methodological aspects of the study are developed, including the previous aspects considered (methodology, sources, etc.). Subsequently, the fifth section presents the results obtained from the study. Finally, the sixth section provides the conclusions and good practices identified in the study that enable improvements in the channelling of the flow of information from the SME to the bank, facilitating and, therefore, improving credit risk rating.

\section{The Problem of Information Asymmetry: Theoretical Underpinnings}

The existence of asymmetric information in credit markets makes it difficult to properly assess the credit risk of SMEs and conditions the decision of banks to grant bank financing (Cardone et al., 2005). This initial situation means that lenders, in this case banks, do not have a priori complete information on the characteristics of the borrowers, in this case SMEs, nor can they anticipate the consequences of the decisions taken by the borrowers until the debt matures. As a result, banks are sometimes unable to effectively assess the credit risk of SMEs and decision-making is complicated. In addition, the lack of information considered relevant for the bank may further impair the credit risk rating (Cuena, 2017).

Financial intermediation theory defines financial intermediaries as information managers (Leland and Pyle, 1977; Tobin, 1987). This theory, in addition to analysing the rationale for the existence of financial intermediaries, explores the possibility that the financial intermediary (bank) and the customer (SME) go beyond a simple and anonymous financial transaction, creating a link in the framework of a longer-term relationship. This link, referred to as the "banking relationship", can 
reduce the effects of asymmetric information in the market and, in turn, allow both parties to get to know each other better, resolving conflicts between them.

In this context, agency theory analyses, among others, the conflicts arising from the existence of asymmetric information in the process of granting financing by banks to SMEs (Diamond, 1984). This theory is essentially based on the risk of adverse selection and moral hazard. Both risks are based on the existence of asymmetric information and are those that banks must try to overcome with their experience and knowledge of the company and the project, as well as through the signals received from the SME (Martín and Sáez, 2001).

Signal theory provides interesting nuances to consider in the process of accessing bank financing for SMEs (Zhao et al., 2009). Traditionally, in order to compensate for the lack of adequate information, banks have used different signals from firms related to the level of risk. These signals from SMEs are aimed at conveying information about their true credit risk situation in an attempt to reduce information opacity. In general, the most reliable and frequently used signals are guarantees and the provision of equity. In addition to these signals, banks rely on the qualitative information generated within the banking relationship between the two parties to help mitigate the problems of information asymmetry.

Although this opacity of information usually originates in SMEs, as mentioned above, it is also detected in banks, specifically in the criteria and/or elements used in the credit risk rating process, which is calculated on the basis of the information collected and the methodology applied by each bank and is therefore the property of the bank. This knowledge, created within the bank, is often "superior to that of competing banks and customers themselves" (Behr and Güttler, 2007, p. 195).

In short, if banks were to share some of the criteria and/or elements considered in credit risk assessment, it would allow SMEs to be aware of the information they need to transmit so that their credit risk rating reflects their real situation. This would improve the flow of information, increasing and standardising the information considered in the credit risk assessment. With this objective in mind, the following is an analysis of the variables that are generally considered by banks when rating credit risk.

\section{Process of Credit Risk Rating by Financial Institutions}

The process of granting credit to SMEs by banks can be summarised in the following three stages, receipt of the SME application, credit risk assessment and decision to grant the requested credit (Figure 1): 
Figure 1. Outline of the financing process

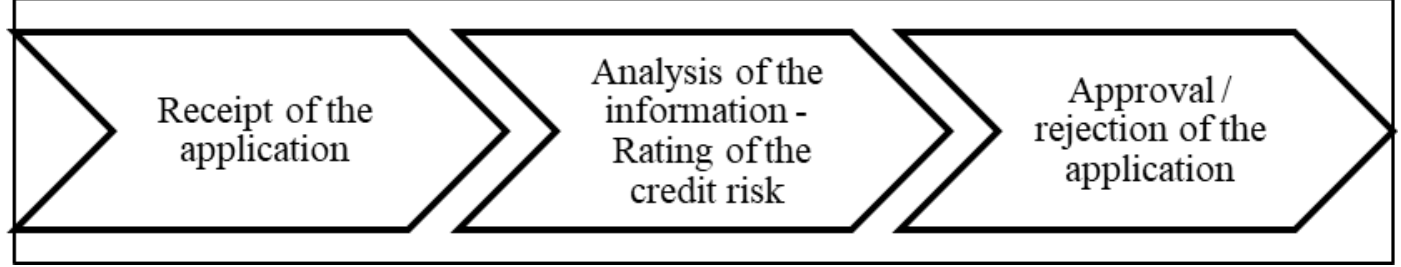

Source: Own elaboration.

Therefore, both to accept or reject a request for financing and to determine the conditions for granting it, banks assess the credit risk of SMEs. This credit risk rating, as mentioned above, is obtained through algorithms and statistical formulas based on the company information collected by the banks.

Credit risk rating is usually performed by analysing and assessing the firm's ability to meet its financial commitments to the bank. In this process, information is "key to the most accurate calculation of risk and the most efficient allocation of finance to SMEs" (Binks and Ennew, 1997, p. 176). Moreover, the information to be considered should be related to the firm's ability to meet its financial obligations, which in turn depends on external factors and factors internal to the company (Gómez and Partal, 2010). In the case of the former, in addition to the country's sovereign risk, which reflects the situation of the economic-financial environment, the characteristics and situation of the sector of economic activity, technological and/or regulatory changes and the conditioning factors of the economic cycle, for example, are taken into account (Díaz et al., 2010). In the case of internal factors, factors related to the company's own characteristics are taken into account. The information is collected directly through the documentation provided by the SME, and indirectly through the contractual and personal relationship between the bank and the SME.

Once the relevant information has been collected, banks generally "combine historical credit information from their customer bases, their expertise in risk portfolio management and the application of statistical techniques" (Díaz et al., 2016, p. 48). As a consequence, the credit risk rating of an SME may vary from one institution to another, due to the different relationships, experiences and information that each of them acquires in relation to the company. To all this must be added the fact that institutions develop and use their own internal credit risk rating methods, in which they weight the different factors according to their criteria, with the importance they give to each type of information differing from one institution to another.

SMEs have an active role to play in this process. The more adequate, sufficient, relevant and reliable the information provided to the bank about their true situation, the less information asymmetry there will be. Taking into account the above, and based on the methodology proposed by Banco de España Circular 6/2016 of 30 June 
2016 (under Law 5/2015 of 27 April 2015 on the promotion of business financing), the information required for credit risk rating can be classified into three main blocks:

- Quantitative variables: relating to financial position and future cash flows.

- Qualitative variables: related to the activity carried out by the SME.

- Behavioural variables: referring to the SME's previous behaviour with banks.

In the case of quantitative variables, in general, banks usually require SMEs to present this information, so it is usually submitted directly when applying for financing. This group includes, on the one hand, information on the economicfinancial situation of the company, which, according to Circular 6/2016, must at least include profitability, liquidity, indebtedness, solvency and activity ratios. The ratios, in addition to reflecting the company's strategic decisions, allow comparison between different companies. Thus, when faced with a set of firms with similar investment projects, those with a weaker financial situation tend to suffer greater restrictions (Gertler and Hubbart, 1998), higher financing costs (Bernanke and Gertler, 1989; Bond and Meghir, 1994) and/or greater requirements for personal guarantees (Hernández and Martínez, 2010).

On the other hand, another type of quantitative variable considered is projection of future cash flows of SMEs. This requires "intellectual work", basically by the entrepreneur or manager (Dapena and Dapena, 2003). This information provided by the company, in addition to conforming to the characteristics of the SME and the sector in which it operates, must be consistent, since it will not be credible to the bank if there are glaring differences. Along these lines, and related to the characteristics of the company itself, which are included in the following block of qualitative variables, better financial results are observed in family businesses (Gonzalez et al., 2019), which may have an impact on the assessment of credit risk.

With regard to the qualitative variables specific to SMEs, in general, this information is more difficult for banks to collect, because it is either partially published or not published at all. This block would include, for example, age, sector of activity to which it belongs, competitive positioning, organisational structure, quality of management, shareholding structure, experience and commitment of the partners, etc., (Díaz et al., 2016; Gómez and Partal, 2010). For example, companies that are better known because of their size and track record get better debt conditions (Petersen and Rajan, 1994; 1995; 2002; Blackwell and Winters, 1997; Angelini et al., 1998; Cardone et al., 1998; Elsas and Krahnen, 1998; Harhoff and Körting, 1998a; Degryse and Van Cayseele, 2000; Machauer and Weber, 2000; Lehmann and Neuberger, 2001; Brau, 2002; Ziane, 2004; Degryse and Ongena, 2005; Hernández and Martínez, 2006; 2010; Illueca and Maudos, 2006; Montoriol, 2006; Bonfim et al., 2008; Brunner and Krahnen, 2010; Larrán et al., 2010). Moreover, according to Botello (2015), on the one hand, the characteristics of the firm's strategic 
management (management qualifications, shareholder concentration, etc.) have a positive effect on access to credit. On the other hand, the sector of activity to which the company belongs and its geographical location also affect the level of access to credit.

Finally, the behavioural variables collect information on the SME's previous behaviour with the bank or other banking institutions. It is worth mentioning that the consolidation of the banking relationship, in addition to collecting historical information on the behaviour of the SME, allows the bank to access its information, reducing the asymmetry of information and thus improving access to credit (Allen et al., 1991; Nakamura, 1992; Berger et al., 1999; Boot, 2000). In other words, an intense and fluid relationship will allow the bank to access the information necessary for a better calculation of the SME's credit risk. In this sense, research generally suggests that a long-lasting and exclusive banking relationship leads to an increase in the availability of financing (Boot and Thakor, 1994; Petersen and Rajan, 1994; Cardone et al., 1998; Cole, 1998; Angelini et al., 1998; Harhoff and Körting, 1998a; Machauer and Weber, 2000; Lehmann and Neuberger, 2001; Fernando et al., 2002; Hernández, 2004; Ziane, 2004; Cardone et al., 2005; De Bodt et al., 2005; Montoriol, 2006; Casasola and Cardone, 2009; Hanley and O'Donohoe, 2009; Hernández and Martínez, 2010).

In summary, it can be concluded that, for credit risk rating, banks take the SME's current information, historical information and projections about its future situation into account. In addition, this information is collected directly through the documentation provided by the SME and indirectly through the work carried out by the banks' rating specialists. Finally, in general, quantitative, qualitative and behavioural variables are used for this information gathering. At this point, the question arises: what are the specific variables considered? What is the importance of each of these variables in the credit risk rating? This study aims to answer these questions and to clarify the type of information that SMEs should transmit to institutions to facilitate and improve both credit risk rating and subsequent access to bank financing.

\section{Data and Methodology}

In this study, a dual methodology was used, both of which are qualitative and complementary, at first, in-depth interviews with specialists and, subsequently, the Delphi method.

The qualitative methodology has been considered appropriate because the information to be obtained is qualitative, i.e., the object of study is not directly observable. Moreover, the characteristics of the phenomenon to be studied are appropriate, dense, overdetermined and concrete (Castro and Castro, 2001). Access to bank financing for SMEs, with a bearing on credit risk rating, can be considered a specific object of analysis because it is carried out within a framework determined 
by the banking institutions. In addition, what is analysed is a specific aspect, i.e., the credit risk rating. Finally, it is considered a dense object of study because banking institutions and the resulting banking relationship are shaped, among others, by rights and obligations, institutionalised and hierarchical forms of organisation, with interactions of different kinds (economic, social, labour, ...), etc.

The use of this qualitative methodology, in addition to describing the facts under study and helping to collect the underlying motivations through data (Pedret, 2003), allows us to address explanatory objectives. Thus, the aim of this study is to look for dependency relationships between variables that serve to predict, in an indicative manner, the development of the bank's decision-making process and, as far as possible, to infer them from the sample to the population.

To this end, a panel of expert representatives of the Spanish banking system were selected. Then, firstly, personal interviews were carried out. Subsequently, once the information has been collected and analysed, the Delphi method was applied. This method carries out a systematic and iterative process, aimed at obtaining and evaluating information and/or opinions, with the objective of obtaining a reliable group opinion from the experts (Landeta, 1999). In terms of typology, a conventional and consensus Delphi is applied, the purpose of which is to analyse and understand complex realities.

Finally, it should be noted that the Delphi method has its drawbacks (Gupta and Clarke, 1996), which have already been considered in this study and, to some extent, overcoming them was attempted. Some of the drawbacks (and possible responses to them) are, firstly, the lower possibility of social retribution for the individual's contribution to the group (a disadvantage with little weight in this study, because the experts insisted on being anonymous and not being mentioned explicitly), secondly, the impunity derived from anonymity, which can generate irresponsible action (a disadvantage relatively resolved in this study as the panel was composed of ten experts with whom the interview had previously been carried out, and it can be controlled by centralising the responses), thirdly, the time required for its carrying out (limited by the number of questions in the questionnaire and the use of the internet to send-receive the questionnaire), and finally, the effort required of the participants (which was limited by the use of measurement scales and by providing lists of reference elements). The procedure followed in the study is detailed below.

\subsection{Preparatory Phase}

This study aimed to acquire the knowledge of professionals involved in the rating of bank credit risk for Spanish SMEs. To this end, a panel of expert representatives of the Spanish banking system was selected to constitute the study sample. The sample used, which will be described below, in comparison with quantitative studies in general, is small and the units that make up the sample were not randomly selected. In order to be able to carry out the logic of inference, a qualitatively representative 
sample of the population under study was sought, with the aim of reproducing "those relationships and structures relevant to a structural understanding of the target population" (Castro and Castro, 2001), that is, a sample with structural representativeness.

To this end, structural relevance criteria have been determined. On the one hand, in terms of categorical relevance features, we took the type of financial intermediaries into account, i.e., those that trade in the Spanish credit market. Based on information from the Bank of Spain, the following population of Spanish banks has been defined (Table 1):

Table 1. Population of credit institutions in Spain

\begin{tabular}{|l|l|}
\hline TYPE OF ENTITY & NUMBER \\
\hline BANKS & $\mathbf{5 1}$ \\
SAVINGS BANK & $\mathbf{2}$ \\
CREDIT UNIONS & $\mathbf{6 1}$ \\
\hline
\end{tabular}

Source: Prepared by the authors on the basis of the Banco de España's Official Register of Institutions (February 2021).

On the other hand, in terms of socio-demographic relevance features, it can be observed that, depending on the different sizes of institutions, their behaviour in the credit market is different. In this respect, the different types of institutions and the different socio-demographic characteristics of each of them translate into individualised business strategies in the credit market. Proof of this are the internal criteria used for the credit risk rating of each one, i.e., "their degree of development and use is very different from one institution to another" (Payo and Pérez, 2016).

In view of the above, the three types of financial intermediaries listed in Table 1 were considered first, as they are the most active in the Spanish credit market. With regard to banks, which are the most active banking institutions in the Spanish credit market, the updated ranking of the main Spanish banks is shown in Table 2.

Based on Table 2, seven banks were selected, of which four belong to the group of the five large financial institutions (Santander, BBVA, CaixaBank and Sabadell) and three to the group of the five medium-sized banks (Bankinter, Kutxabank and Abanca).

In addition to the aforementioned banks, credit cooperatives were included, mainly because of their uniqueness in terms of territoriality. At present, most of them are rural credit cooperatives, as well as a popular savings bank and two professional savings banks. Taking this reality into account, it was decided to include the Caja Rural de Navarra and the Caja Laboral Popular de Mondragón respectively. Caja Rural de Navarra ranks first in the Caja Rural group in terms of economic-financial 
situation and Caja Laboral Popular de Mondragón is the only popular cooperative ${ }^{7}$ that currently exists in Spain. In the case of savings banks, due to their token number, neither of the two existing in Spain was included.

Table 2. Top Spanish banks by total assets and market capitalisation ${ }^{8}$

\begin{tabular}{|c|c|c|c|c|c|c|c|c|c|c|}
\hline & CONSC & DLID & ATED B $A$ & ALAN & CE SH & HEETS & & & & \\
\hline $\begin{array}{l}\text { Figures in millions o } \\
\text { euros }\end{array}$ & $\begin{array}{l}\text { Banco } \\
\text { Santan } \\
\text { der }\end{array}$ & BBV & $\begin{array}{l}\text { CaixaB } \\
\text { ank }\end{array}$ & \begin{tabular}{|l} 
Banc \\
o \\
Saba \\
dell \\
\end{tabular} & $\begin{array}{l}\text { Bank } \\
\text { ia }\end{array}$ & $\begin{array}{l}\text { Banki } \\
\text { nter }\end{array}$ & $\begin{array}{l}\text { Kutxab } \\
\text { ank }\end{array}$ & $\begin{array}{l}\text { Aba } \\
\text { nca }\end{array}$ & $\begin{array}{l}\text { Unic } \\
\text { aja } \\
\text { bank }\end{array}$ & $\begin{array}{l}\text { Iberc } \\
\text { aja }\end{array}$ \\
\hline $\begin{array}{l}\text { TOTAL ASSETS } \\
\text { (intermediate data } \\
30 / 06 / 2020 \text { ) }\end{array}$ & $\begin{array}{l}1,572,8 \\
81\end{array}$ & $\begin{array}{l}753,8 \\
23\end{array}$ & 445,572 & $\begin{array}{l}234,4 \\
47\end{array}$ & & 92,828 & 64,215 & $\begin{array}{l}63,32 \\
6\end{array}$ & $\begin{array}{l}62,97 \\
1\end{array}$ & $\begin{array}{l}58,09 \\
6\end{array}$ \\
\hline $\begin{array}{l}\text { Market capitalisation } \\
\text { (data at Decembe } \\
2020)\end{array}$ & $\mathrm{r} 44,010$ & $\begin{array}{l}26,90 \\
4\end{array}$ & 12,567 & 1,991 & 2,668 & 3,976 . & & & 1,129 & \\
\hline
\end{tabular}

Source: Prepared by the authors based on information from the Spanish Banking Association (AEB), financial reports from banks and Bolsas y Mercados Españoles (BME).

Finally, Elkargi S.G.R. was included, due to the role played by the Mutual Guarantee Societies (MGS) in access to bank financing for SMEs. There are currently 18 Mutual Guarantee Societies (MGS) in Spain ${ }^{9}$, with Elkargi being the leader among them ${ }^{10}$. As a result, the institutions selected for analysis of Spanish SMEs' access to bank financing are as listed in Table 3. This initial panel was maintained until the end of the study thanks to the in-depth interviews prior to the application of the Delphi method, which allowed for greater commitment of the participants to the study.

In summary, the sample configuration was carried out, on the one hand, following the principle of homogeneity, that is, a similar way of working; and, on the other hand, following the principle of heterogeneity, considering positions that provide a

\footnotetext{
${ }^{7}$ Due to the low representativeness of professional savings banks, it was decided not to include any of this type. Specifically, professional savings banks represent less than $1 \%$ of the total number of credit cooperatives at territorial level (number of bank branches) and approximately $2 \%$ in economic-financial terms (assets, liabilities and net worth) (Alda et al., 2017).

${ }^{8}$ The data collected in this table are the most current and homogeneous data corresponding to the entities that make up the sample for the fieldwork carried out between July 2018 and November 2019 (without yet incorporating the latest modifications produced in the sector) so as not to distort the configuration of the sample.

${ }^{9}$ Cesgar. Spanish Confederation of Mutual Guarantee Societies.

${ }^{10}$ On 1 January 2017, the so-called new Elkargi was created as a result of merger by absorption between the two Basque MGSs (Elkargi and Oinarri), giving rise to the "undisputed leader among Spanish MGSs" (http://www.cesgar.es/luz-verde-en-elkargi-yoinarri-a-una-fusion-que-movilizara-1-000-millones-en-creditos-al-ano/, 01/10/2018).
} 
certain difference between them. The aim is for the sample to be qualitatively representative of the population under study and, thus, to have the possibility of extrapolating some of the conclusions obtained from the sample to the population as a whole.

Table 3. Participating entities of the expert panel

\begin{tabular}{|l|l|}
\hline FINANCIAL INSTITUTION & TYPE \\
\hline Banco Santander & Bank \\
BBVA & Bank \\
Caixabank & Bank \\
Banco de Sabadell & Bank \\
Bankinter & Bank \\
Kutxabank & Bank \\
Abanca & Bank \\
Caja Rural de Navarra & Credit union \\
Caja Laboral Popular de Mondragón & Credit union \\
Elkargi & Mutual Guarantee Society \\
\hline
\end{tabular}

Source: Own elaboration.

\subsection{Expert Panel, Questionnaire and Consultation Phase}

Once the study sample, composed of the entities listed in Table 3, had been selected, the SME credit risk rating professionals, experts both in terms of their knowledge and their outstanding professional experience, were contacted. Consequently, they all belong to the category of "specialists"11. This is therefore a study of specialists. The participation of the experts was voluntary, and they were always willing and cooperative.

Professionals in general, and in particular those participating in this sample, being familiar with face-to-face interviews, did not need an a priori extensive explanation. The questionnaire sent out within the framework of the Delphi method was drawn up on the basis of the information obtained from the interviews and the review of the bibliography of previous studies. The typology of the questions, according to the type of response requested, is of three types: Likert type (evaluating in an interval), weighting (assigning a place in ascending or descending order) and open-ended (issuing commented evaluations). These questions, in turn, are grouped into three blocks. On the one hand, questions aimed at identifying in greater detail the three types of information considered in the credit risk rating (quantitative, qualitative and behavioural information), and on the other hand, a question that obliges the specialists to determine the weight that each type of information may have in the final rating. Finally, the last two questions invited the experts to make recommendations or suggest good practices that will enable SMEs to better convey information on their situation.

\footnotetext{
${ }^{11}$ The opinion expressed by the interviewee was given in a personal capacity; it does not commit or bind the institution to which they belong.
} 
After analysing the results and drawing the main conclusions from the first round, a second and final round was held, in which each expert received the questionnaire with his or her answers, together with the group answers, and was asked to reevaluate his or her evaluations. In the second and final round, the desired degree of stability and consensus ${ }^{12}$ between the opinions of the participants was achieved.

Finally, it should be noted that the participation of the selected experts, both in the personal interview and in the first and second round, was $100 \%$. In other words, a total response success rate was achieved, maintaining the initial sample. The technical aspects of the qualitative study are listed in Table 4.

Table 4. Qualitative Study Fact Sheet

\begin{tabular}{|l|l|l|}
\hline Methodology & Phase 1: in-depth interviews & $\begin{array}{l}\text { Phase 2: sending out of } \\
\text { questionnaires, consisting of 11 } \\
\text { questions, within the framework } \\
\text { of the Delphi method. }\end{array}$ \\
\hline Procedure & $\begin{array}{l}\text { Two interviewers with each } \\
\text { specialist. Interviews } \\
\text { recorded and transcript } \\
\text { generated. }\end{array}$ & $\begin{array}{l}\text { Sending the questionnaire by e- } \\
\text { mail, accompanied by a cover } \\
\text { letter containing the practical } \\
\text { conditions relating to the } \\
\text { questionnaire. }\end{array}$ \\
\hline $\begin{array}{l}\text { Profile of the experts } \\
\text { interviewed }\end{array}$ & $\begin{array}{l}10 \text { experts were interviewed: } 60 \% \text { branch managers (corporate } \\
\text { section, G2) and 40\% risk analysts (G1). }\end{array}$ \\
\hline $\begin{array}{l}\text { Date of fieldwork } \\
\text { July-December 2018 }\end{array}$ & $\begin{array}{l}\text { First round: February-April 2019 } \\
\text { Second round: May-November } \\
2019\end{array}$ \\
\hline $\begin{array}{l}\text { Average length of } \\
\text { interviews/questionnaire }\end{array}$ & 1 hour and 10 minutes & $\begin{array}{l}\text { Estimated time for completion of } \\
\text { the questionnaire: 30 minutes }\end{array}$ \\
\hline
\end{tabular}

Source: Own elaboration.

\section{Results}

\subsection{Analysis of the Process}

Before moving on to the analysis of the results, first of all, the information collected was filtered to determine the number of valid answers to each question. Thus, in this study, the ten experts who participated answered all or most of the questionnaire, although it is worth mentioning that some answers with errors were identified, which were not considered in the analysis.

Next, the statistical treatment of the experts' assessments was carried out. To do this, the resulting information was processed by determining the measures of central tendency and dispersion. The mean and the interquartile range $(0.25)$ were used to

\footnotetext{
${ }^{12}$ The $25 \%$ percentile has been considered as consensus and stability, i.e. $75 \%$ of the experts' observations are higher than this value.
} 
analyse the average behaviour and the minimum valuation established by $75 \%$ of the responses, in order to determine the consensus valuation of the experts. The standard deviation was been determined to analyse the dispersion of the responses.

This process was initially carried out by taking all the experts as a reference. Furthermore, in order to make a more exhaustive comparison, the process was repeated by differentiating the assessment of the group of risk analysts (G1: 4 experts) and the group of branch managers (corporate section) (G2: 6 experts), thus making it possible to compare the assessments according to the experience and/or type of work they perform.

\subsection{Analysis of Results}

The analysis of the results follows the structure of the questionnaire. First, the information relating to the three types of variables considered in the credit risk rating - quantitative, qualitative and behavioural information - is analysed. Next, the responses on the weight that each type of information may have in the final rating are considered. Finally, in view of the open-ended nature of the questions, which makes subsequent statistical treatment impossible, this information is analysed by synthesising the contributions made by the experts.

Firstly, and with regard to the quantitative variables relating, above all, to the economic and financial situation of the SME, the results (see Figure 2 and Annexes Table 1) show that the experts unanimously consider that SMEs need to provide a balance sheet and profit and loss account, with an average score of 5 points out of 5 .

In addition, there is a broad consensus in the assessment of the importance of the audit report and corporation tax (average of 4.9 and 4.6 points, respectively), while the documents relating to VAT settlement and the declaration of transactions with third parties have an average rating of 3.7 points. Depending on the profile of the experts, it can be seen that, in general, the importance attached to the request for this type of documentation by the group of risk analysts (G1) is slightly lower than in the group of branch managers (company section) (G2).

Analysing the $25^{\text {th }}$ percentile value of the experts' assessment of the documentation to be submitted to obtain quantitative information, as in the analysis based on the mean, a high level of consensus can be seen in the documents mentioned above (equal to or higher than 4 points, except for VAT settlement (3 points) and declaration of transactions with third parties (3.25)). It can therefore be deduced that, in general, the average behaviour and the minimum rating established by $75 \%$ of the responses are in line with each other. 
Figure 2. Documentation to be submitted

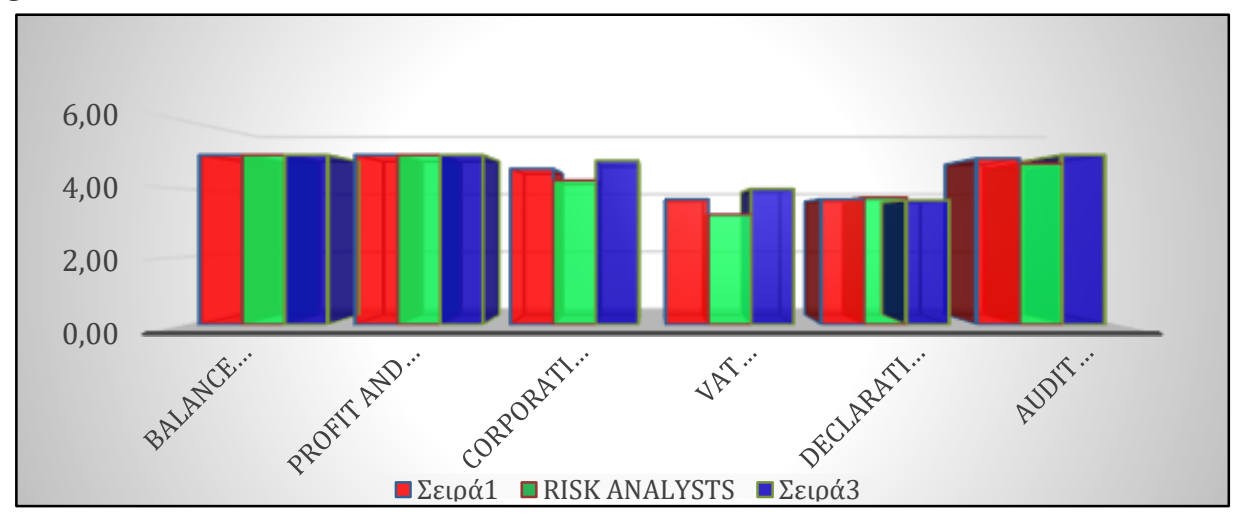

Source: Own elaboration.

Secondly, with regard to the qualitative variables, aspects related to the activity carried out by the SME, the organisational structure and characteristics of management staff, the information and control systems of the SME, etc. are collected. With regard to the information on the purpose of the project that is the subject of the financing application and the cash flow projection (forecast data, viability plan, cash flow plan, strategic plan) (see Figure 3 and Annexes Table 2), there is broad consensus on its importance (average of 4.8 in the case of the purpose and four experts unanimously rated the projections with 4 points). Specifically, the purpose of the project that is the subject of the financing application obtained an average score of 5 for the group of risk analysts (G1) and slightly lower (4.60) for the group of branch managers (business section) (G2).

Among the rest of the results, the most highly rated variable is the involvement of the owners with 5 points. Next, the quality of the management team (4.30 points), shareholder structure (4.10), competitive positioning (3.90 points), seniority (3.80 points) and market share (3.60 points) are the variables with the highest scores. The lowest rated variables were: legal form (2.30 points), obtaining quality certificates (2.40 points), workforce (3.11 points) and company size (3.5 points).

However, this ranking varies according to the experts' reference group. If variables with a mean of 4 or more are analysed, the group of risk analysts (G1) would include seniority, while for the group of branch managers (corporate section) (G2), competitive positioning would be added.

Among the qualitative variables, it is worth mentioning the visit to the SME, a variable that was detected as a result of the interviews prior to the application of the Delphi method and which it was decided to include in the questionnaire. According to the experts, an average of $80 \%$ of the applications analysed usually require a visit to the company in order to make a decision on the application for bank financing of an SME. In the cases in which a visit is made, among the characteristics or aspects 
that have been raised (see Figure 4 and Annexes Table 3), the variables premises, workers and offices were valued by all the experts, with averages of 3.90 points, 3.90 points and 3.20 points, respectively. Furthermore, it can be seen that the mean values of the premises and office variables are higher in the group of branch managers (company section) (G2) than in the group of risk analysts (G1), while the mean value of the workers is higher in the group of risk analysts (G1). With reference to the percentiles, the percentile for workers is of note, with a percentile of 4 points in general, being in the case of premises and offices approximately 3 points.

Figure 3. Non-financial variables

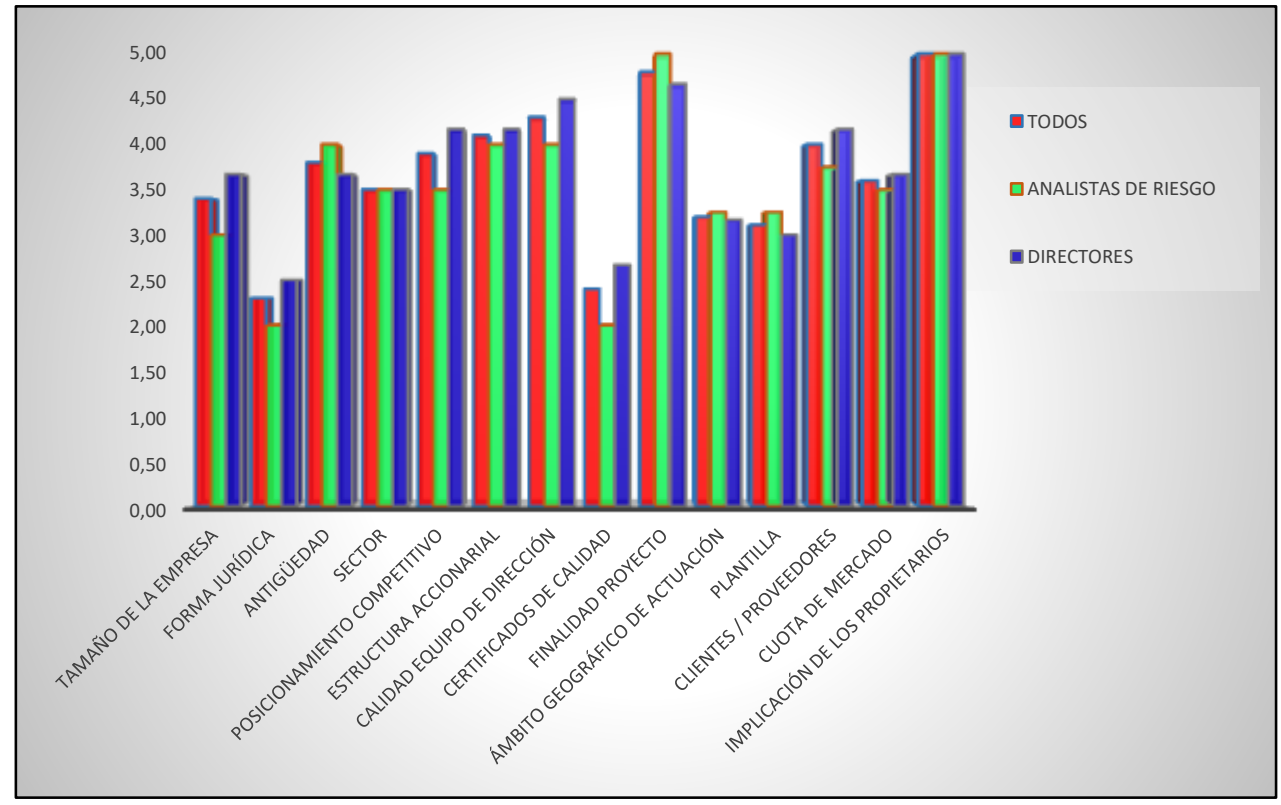

Source: Own elaboration.

Figure 4. Relevant aspects of the visits

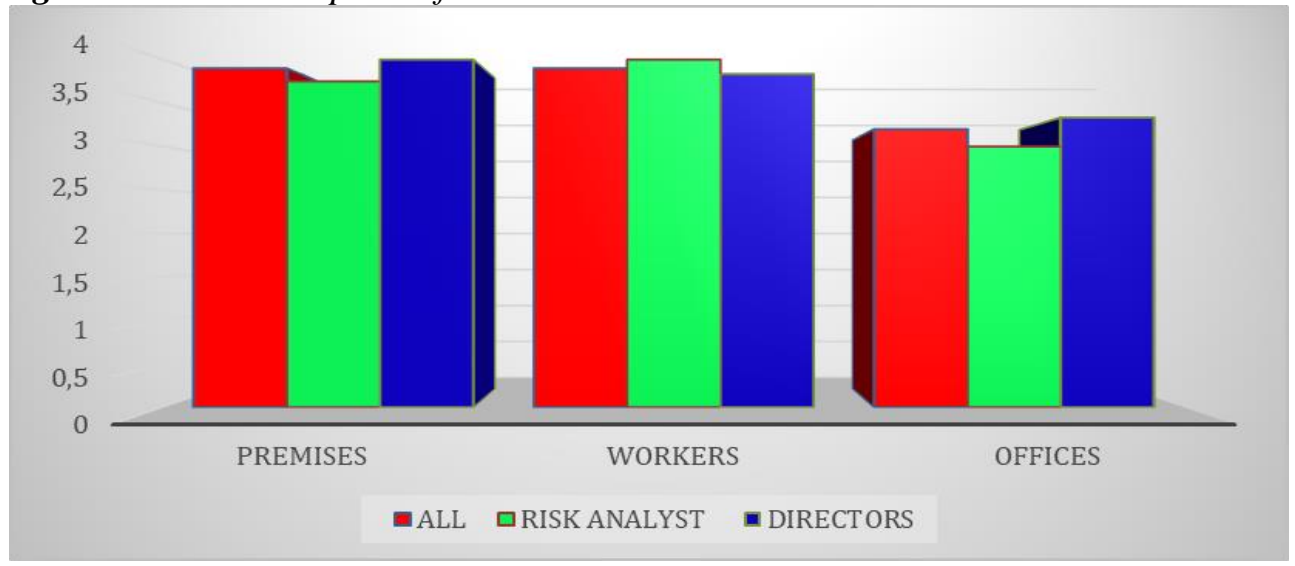

Source: Own elaboration. 
Thirdly and finally in the case of the behavioural variables, information was collected on the SME's previous behaviour with the bank or other banking institutions. Thus, the characteristics of the SME's banking relationship with the bank have been analysed (see Figure 5 and Annexes Table 4). Among the results, it is noteworthy that, in the case of all the variables considered, the means in the group of risk analysts (G1) are higher than in the group of branch managers (business section) (G2), with the standard deviations being higher in the latter group. It follows that these variables have a higher degree of importance for the group of risk analysts (G1) when analysing SME credit risk.

This is illustrated by the fact that all experts in the risk analyst group (G1) rate the variables banking pool, credit history and default frequency at 5 points, while the average rating of these three variables is lower for the experts in the branch managers (company section) group (G2) (banking pool with 4.40 points; credit history and default frequency with 4.80 points; followed by overdrafts with 4.20 points). The level of trust is the only variable with a different behaviour, as it has a slightly higher average score in the group of branch managers (corporate section) (G2) (4.60) than in the group of risk analysts (G1) (4.50). The analysis using the $25^{\text {th }}$ percentiles leads to the same conclusions. In addition, and comparing with the mean values collected for both quantitative and qualitative variables, the mean values of this group of variables show a great consensus as to the high importance of these variables when assessing credit risk.

As for the overdrafts, duration and number of financial products contracted variables, the average scores were 4.33 points, 3.89 points and 3.67 points, respectively, the latter being the lowest of all the banking relationship variables considered.

Lastly, and related to the behavioural variables, as regards the additional documents most commonly used to gather information, unanimity was found with respect to the Central Credit Register of the Banco de España (CIRBE), which obtained an average score of 4.90 points. Specifically, all the risk analysts and 5 of the 6 branch managers (corporate section) give it the highest score. Moreover, 9 of the 10 experts additionally use the INFORMA source, although their assessment of it is not unanimous (average of 3.44 points), with a fairly high deviation (1.01 for all experts; 0.96 for $\mathrm{G} 1$; and 1.10 for $\mathrm{G} 2$ ).

Having analysed the results relating to the first block, on the information relating to the three types of variables considered in the credit risk rating, the responses to the second block, relating to the importance and weight that each type of information may have in the final rating, are analysed. In this respect, on the one hand, the three types of variables considered in the credit risk rating have their importance (see Figure 6 and Annexes Table 5) in determining the final credit risk rating, all of them with an average score of more than 4 out of 5 . In general, the quantitative variables (average of 4.78 points) are more highly rated than the qualitative variables (4 
points), but the latter are less highly rated than the variables referring to the banking relationship (4.11 points). These results hold for the group of risk analysts (G1), but not for the group of branch managers (company section) (G2), as the variables corresponding to the banking relationship are the least valued by them.

\section{Figure 5. Characteristics of the banking relationship}

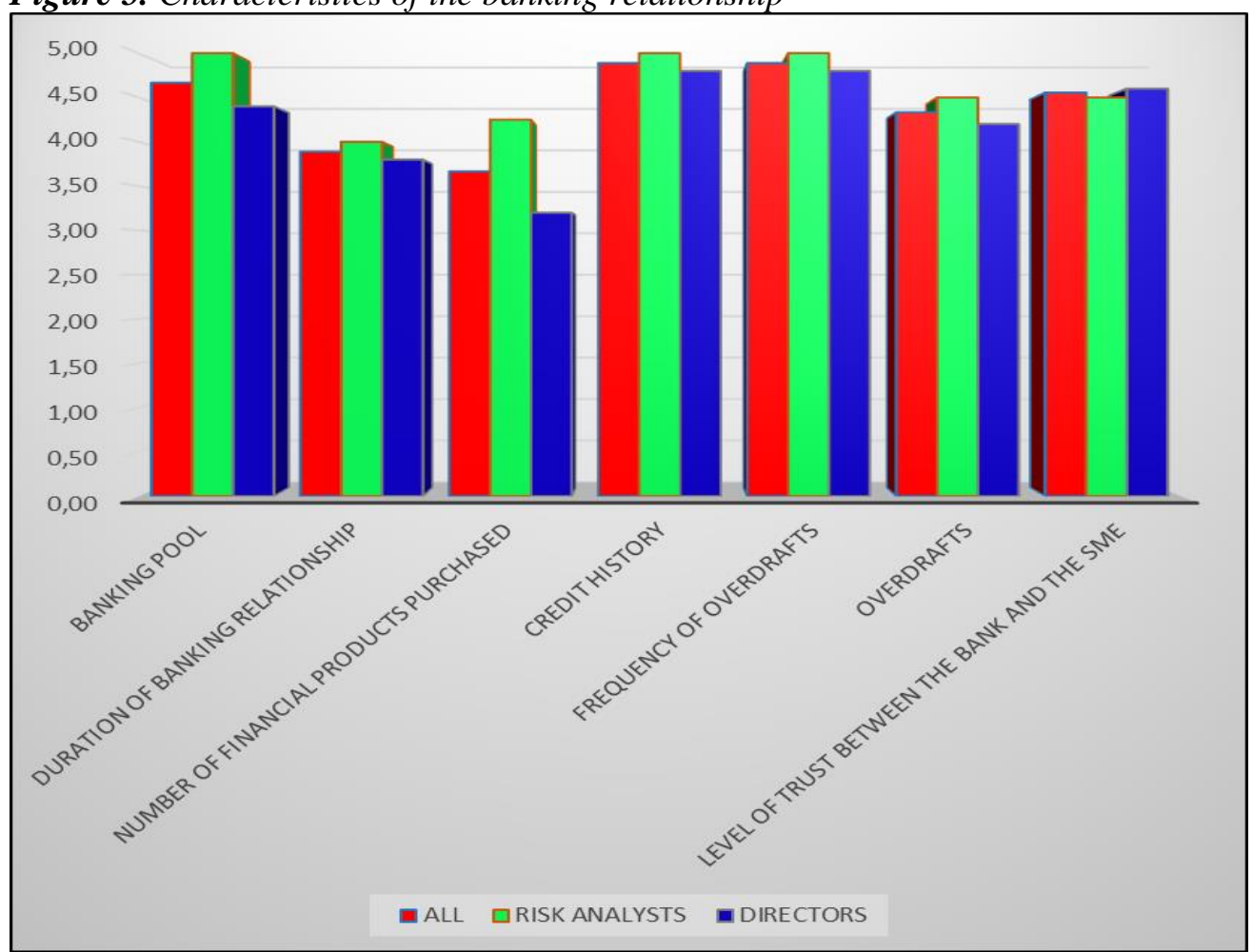

Source: Own elaboration.

On the other hand, with respect to the weight assigned (percentage) by the experts to each group of variables in the final credit risk rating (see Annexes Table 6), the quantitative variables were around twice as important as the qualitative variables, $55 \%$ and $24 \%$ respectively. For the group of branch managers (business section) (G2) the relationship is similar, but not for the experts in the group of risk analysts (G1). For the latter, the percentage importance of quantitative variables is $60 \%$, followed by the most valued variables corresponding to the banking relationship (23\%), with the lowest percentage corresponding to qualitative variables with $17 \%$ importance.

Continuing with the analysis of the weight assigned to each group of variables by the experts, Figure 7, corresponding to the quantitative variables, shows that no expert 
gave them less than $20 \%$ importance, while $44.44 \%$ of the experts gave them a weight of $40-60 \%$.

\section{Figure 6. Importance of variables}

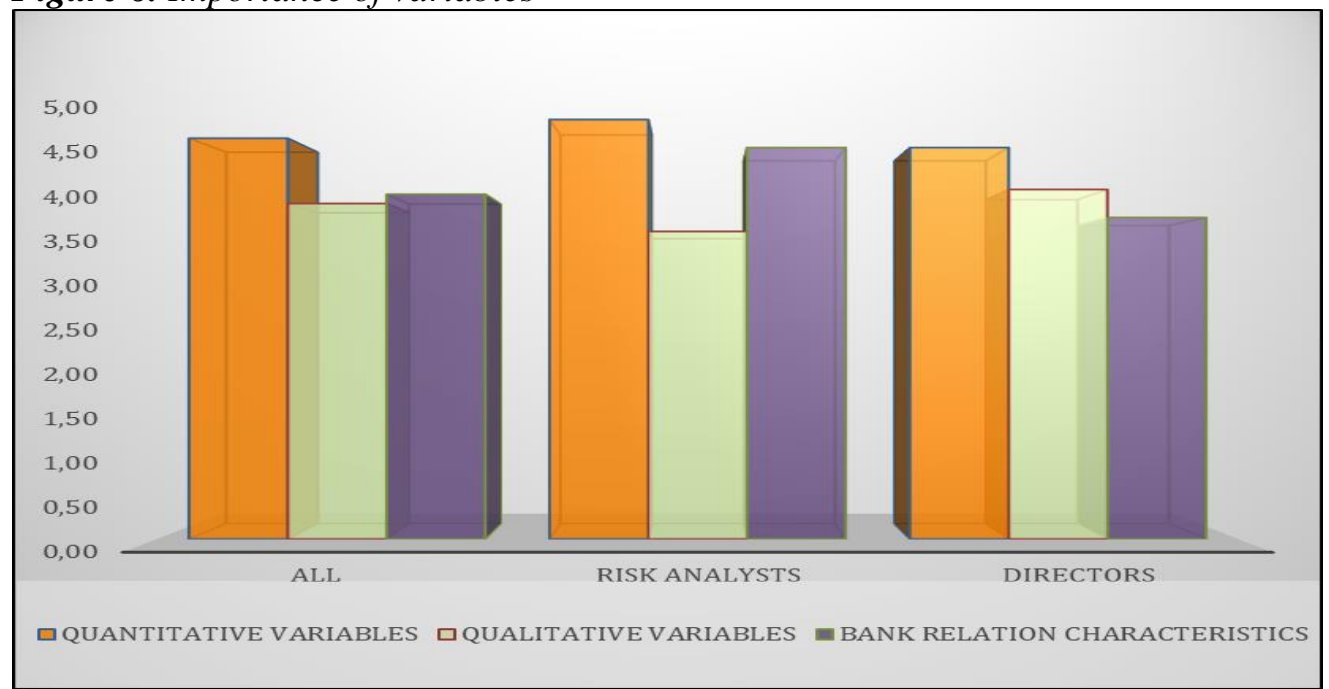

Source: Own elaboration.

Figure 7. Average weight assigned to the quantitative variables

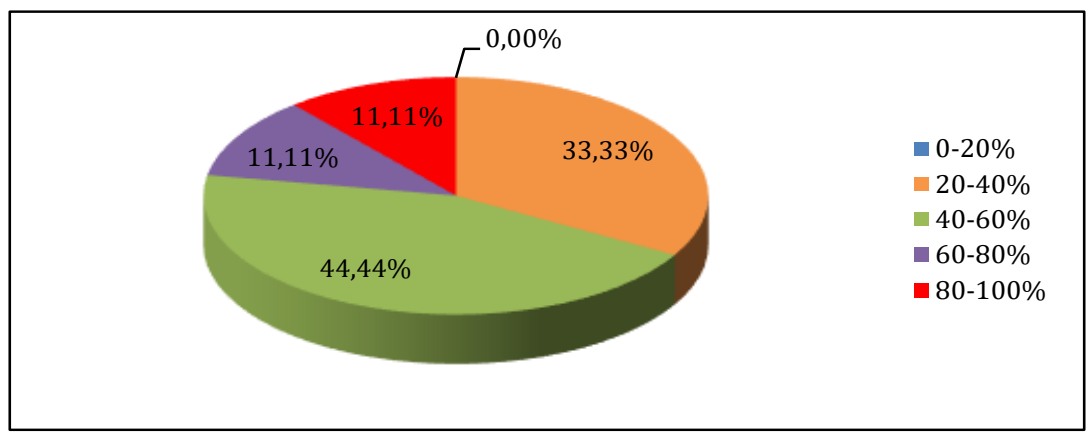

Source: Own elaboration.

In the case of the qualitative variables (Figure 8), the weightings are lower, as no expert weighted them with more than $60 \%$, while slightly more than half of the experts $(55.56 \%)$ valued them with a weight of less than $20 \%$. 
Figure 8. Average weight assigned to qualitative variables

Source: Own elaboration.

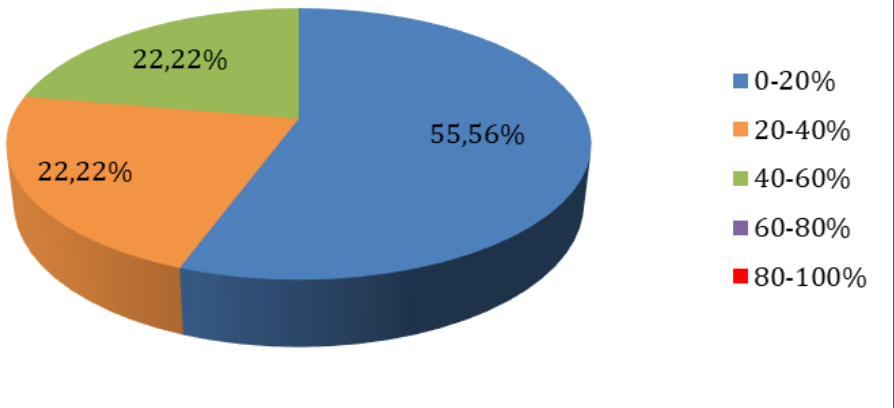

Figure 9. Average weight assigned to the banking relationship

\section{Source: Own elaboration}

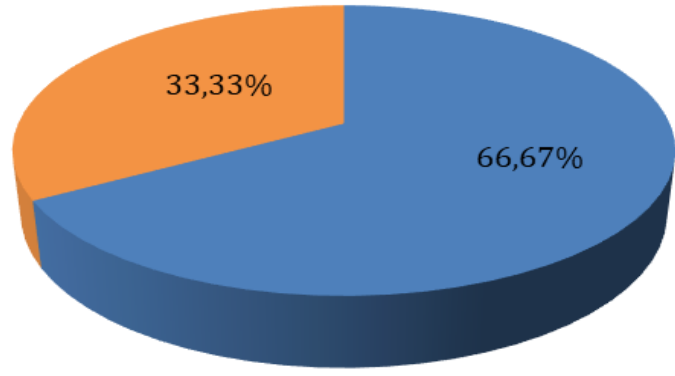

- $0-20 \%$

$\square 20-40 \%$

- $40-60 \%$

- $60-80 \%$

- $80-100 \%$

Finally, Figure 9 shows the weight assigned by the experts to the variables referring to the banking relationship. As can be seen, no expert assigned them a weight of more than $40 \%$ and two thirds of the experts valued them with less than $20 \%$ importance. However, one third of the experts, on the other hand, valued them with a weight of $20-40 \%$.

To conclude the analysis of the results, the answers of the third and last block are analysed, in which open questions were posed inviting the experts to make recommendations or suggest good practices that would allow SMEs to better convey information on their situation. The contributions made by the experts are summarised in Figure 10 (see Annexes Table 7).

As can be seen, all experts suggest that the most important thing is transparency in the information presented regarding the situation of the SME. In addition, the provision of orderly, up-to-date and substantiated information is highly valued, and, finally, a good attitude on the part of the applicant (all of them with a rating of 4 or more out of 5). In the specific case of the group of risk analysts (G1), all these 
behaviours are considered even more relevant (with a rating between 4.75 and 5), while for the group of branch managers they are less so.

\section{Figure 10. Transmission of information}

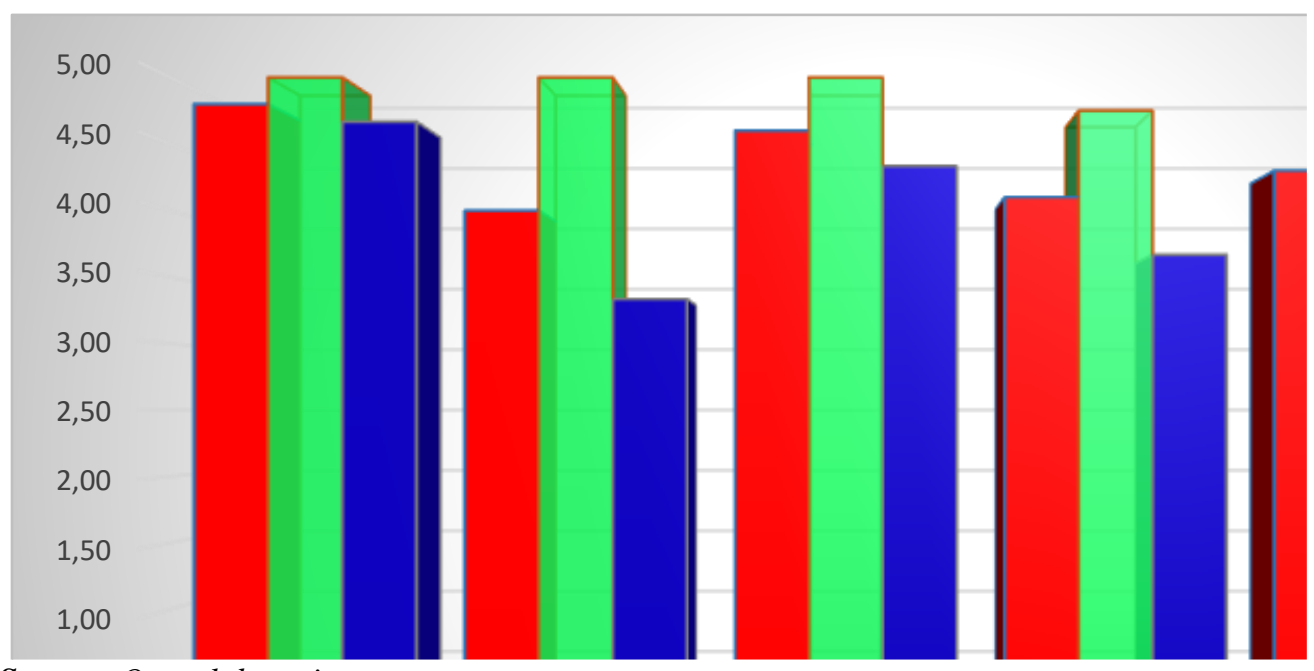

Source: Own elaboration.

In other words, it can be concluded that the more and better the information presented by the SME to the banks, the easier the credit risk analysis work will be, and the lower the penalties due to lack of information will be. To achieve this, the company must present the information in a transparent, orderly, up-to-date and substantiated manner, together with a good attitude on the part of the SME during the information gathering process. This helps to improve the bank's perception of the reliability of the data submitted, which may result in facilitating and improving the SME's credit risk rating.

\section{Conclusions}

The aim of this paper is, firstly, to identify the elements banks consider when assessing the credit risk of SMEs and, subsequently, to propose actions aimed at helping them to transmit reliable information on their credit quality. This would improve the flow of information between companies and institutions and help to reduce the problem of information opacity, which, as Cardone et al. (2005) point out, can condition access to bank financing.

Firstly, the review of the existing literature on signal theory (Zhao et al., 2009) allows us to affirm that all those signalling actions carried out by SMEs and related to the level of credit risk help to reduce information asymmetries, improving the credit risk rating of SMEs and affecting access to bank financing. In this respect, one of the first conclusions is that SMEs should play an active role in the transmission of information on their risk situation. Specifically, based on the results obtained in the 
third block of the study, banks value positively the fact that the information provided by SMEs is transparent, as well as orderly, up-to-date and well substantiated.

Secondly, with regard to the importance and weight of the three types of variables (quantitative, qualitative and behavioural) analysed in this research in credit risk rating, it is concluded that quantitative variables are not the only relevant variables, although their greater importance is confirmed, followed by behavioural variables and, lastly, qualitative variables. Along these lines, as was intuitive and logical, it is confirmed that the weight of quantitative variables in the final credit risk rating is slightly more than half.

However, it should not be forgotten that qualitative and behavioural variables account for almost the other half of the final rating, which corroborates the findings of Allen et al. (1991), Nakamura (1992), Berger et al. (1999) and Boot (2000) regarding the importance of these variables in reducing information asymmetry and improving access to credit.

Based on the first two conclusions, an active behaviour, based on information from the SME to its bank, would be in its own interest, especially if it is non-financial information. This type of information represents an important part of credit risk rating and, moreover, as Díaz et al. (2016) and Gómez and Partal, (2010) indicate, it is more difficult for banks to obtain. In this regard, it is important to bear in mind that institutions use information systems that collect both financial and non-financial information to make decisions on the granting of financing. Financial information is mainly collected directly through the documentation provided by the SME. Nonfinancial information is generally collected indirectly, thanks to the work carried out by the banks' risk rating specialists. It is on these latter variables that SMEs can act to reduce possible information asymmetries. This requires, on the one hand, improving the transfer of information on qualitative variables. On the other hand, it is necessary to be aware of the importance of behavioural variables and to take them into account in the establishment of the banking relationship.

Thirdly, as regards the degree of importance given to each type of variable in the granting of financing, quantitative variables, in line with Gertler and Hubbart (1998), Bernanke and Gertler (1989) and Bond and Meghir (1994), are the most relevant. There was unanimity among experts on the type of documentation to be provided by the SME, balance sheet, profit and loss account, audit report and corporation tax. In this respect, institutions value the quality of the information provided by SMEs in terms of transparency, order, timeliness and justification.

In terms of qualitative variables, among those considered by the banks, the purpose of the project stands out. It is advisable for SMEs to make an effort to provide information on the purpose of the project, in order to help transmit more and better information to the bank. In this respect, one way to improve the transmission of information to the banks is through professional management by the SMEs. A 
professional and adequate level of management results in the generation of information necessary for their own management that could be provided to banks in the process of credit risk analysis. This way of operating would help to meet the quality requirements that banks set when assessing the information provided by SMEs.

Furthermore, there is some agreement on the importance of information on the involvement of the company's owners and the quality of its management team, as well as its competitive positioning and market share, according to Díaz et al. (2016) and Gómez and Partal (2010). This type of qualitative information is more difficult for banks to collect and, therefore, if the company is able to transmit it in a transparent and reliable manner, it will improve its credit risk assessment process.

In addition to these variables, the study shows that banks are increasingly requiring visits to SMEs ( $80 \%$ on average of the applications analysed usually require a visit to the company as a condition for a decision on the application for financing). This result leads to the conclusion that one way for banks to obtain qualitative information is to visit SMEs. In this sense, it is important for SMEs to know that the aspects most considered in the visits are the premises, the workers and the offices.

In the case of the behavioural variables, it is concluded that the type of banking relationship established between the SME and the banks is important, due to the impact it has on the final credit risk rating. Other aspects to be considered by the SMEs include the banking pool, the credit history with the bank or other institutions and the frequency of defaults.

In conclusion, the information asymmetry identified by Diamond (1984) is one of the main reasons for the problems of access to bank financing for SMEs. One of the main reasons for these asymmetries is, among other factors, the limited availability of information on the financial situation of SMEs.

This opacity within the company itself translates into limited information transparency towards the outside world, which is due not only to the scarcity of information, but also to the lesser homogeneity of information compared to large companies.

In this context, it can be seen that, in order to reduce this problem, an attempt could be made to generate more and better quality information within the companies themselves, and subsequently transmit it to the banks in the terms that both risk analysts and branch managers have stated throughout this research. In other words, in order for the collection and transmission of information from SMEs to banks to be as appropriate as possible for the correct credit risk rating, it is necessary to know what type of information banks require. This has been one of the objectives of this study and we consider that some of the results obtained could help SMEs to better focus their efforts in managing the necessary and relevant information. Therefore, it 
can be concluded that the more orderly, up-to-date and substantiated the information provided by SMEs is, the more transparency it conveys to banks about their real situation. This would have a positive impact on the final credit risk rating of the SME, favouring a better allocation of financial resources in the credit market which, in turn, would contribute to economic growth (Rajan and Zingales, 1998).

\section{References:}

Alda, M., Asso, J.L., Marco, I. 2017. Las cooperativas de crédito en España tras la reestructuración del sector financiero. Aposta. Revista de Ciencias Sociales, 75, 98121.

Allen, F., Gale, D. 1999. Bubbles, crisis, and policy. Oxford Review of Economic Policy, 15 (3), 9-18.

Angelini, P., Di Salvo, R., Ferri, G. 1998. Availability and cost of credit for small businesses: customer relationships and credit cooperatives. Journal of Banking and Finance, 22(6-8), 925-954.

Spanish Banking Association. 2020. Financial statements. https://www.aebanca.es/estadosfinancieros/

Banco de España. 2012. Guía para la elaboración de la matriz de riesgos. Madrid: Banco de España.

Banco de España. 2021. General information. BE. Registers of institutions updated as at 11 February 2021. https://www.bde.es/f/webbde/SGE/regis/ficheros/es/renl184.pdf.

Bebzcuk, N. 2000. Asymmetric information in the financial markets. Cambridge: Cambridge University Press.

Behr, P., Güttler, A. 2007. Credit Risk Assessment and Relationship Lending: An Empirical Analysis of German Small and Medium-Sized Enterprises. Journal of Small Business Management, 45(2), 194-213.

Berger, A.N., Udell, G.F. 1995. Relationship lending and lines of credit in small firms finance. Journal of Business, 68(3), 351-381.

Berger, A.N., Udell, G.F. 1998. The economics of small business finance: the roles of private equity and debt markets in the financial growth cycle. Journal of Banking and Finance, 22(6-8), 613-673.

Berger, A.N., Bonime, S.D., Covitz, D.M., Hancock, D. 1999. Why are bank profits so persistent: the roles of product market competition, informational opacity, and regional/macroeconomics shocks. Finance and Economics Discussion Series, Board of Governors of the Federal Reserve System (U.S.).

Bernanke, B., Gertler, M. 1989. Agency Cost, Net Worth, and Business Fluctuations. American Economic Review, 79(1), 14-33.

Binks, M.R., Ennew, C.T. 1997. The relationship between UK banks and their small business customers. Small Business Economics, 9, 167-178.

Blackwell, R., Winters, D.B. 1997. Banking relationships and the effect of monitoring on loan pricing. Journal of Financial Research, 20(2), 275-289.

Bolsas y Mercados Españoles. 2020. Annual Report. Available at: https://www.bmerv.es/docs/SBolsas/InformesSB/anual.pdf.

Bond, S., Meghir, C. 1994. Financial constraints and company investment. Institute for Fiscal Studies, 15(2), 1-18.

Bonfim, D., Dai, Q., Franco, F. 2008. The number of bank relationships and the cost of borrowing. An empirical study. In: Soares, O.J. Pina, M. Catalao-Lopes., Ed., New developments in financial modelling. Cambridge Scholars Publishing, 5-33. 
Boot, A. 2000. Relationship banking: what do we know? Journal of Financial Intermediation, 9(1), 7-25.

Boot, A., Thakor, A. 1994. Moral hazard and secured lending in an infinity repeated credit market game. International Economic Review, 35, 899-920.

Brau, J.C. 2002. Do banks price owner-manager agency costs? An examination of small business borrowing. Journal of Small Business Management, 40(4), 273-286.

Brunner, A., Krahnen, J.P. 2010. Hold-up in multiple banking: evidence from SME lending. Centre for Financial Studies Working Paper 2010/07, 1-49.

Caminal, R. 1995. El papel de las restricciones del crédito y las políticas públicas en la financiación de la pequeña y mediana empresa. Papeles de Economía Española, 65, 224-234.

Cardone, C., Longarela, I., Camino, D. 1998. Capital market inefficiencies, credit rationing and lending relationships in SMEs. WP9827(02) Business Economics Series, Universidad Carlos III de Madrid, 1-32.

Cardone, C., Casasola, M.J., Samartín, M. 2005. Do banking relationships improve credit conditions for Spanish SMEs? Working Paper 05-28, 1-36. Business Economics Series 06, Departamento de Economía de la Empresa, Universidad Carlos III Madrid.

Casasola, M.J., Cardone, C. 2009. Too important to fail: do banking relationships favour the credit situation of Spanish SMEs?. Universia Business Review, 4th quarter, 12-29.

Castro Nogeuira, M., Castro Nogueira, L. 2001. Issues in qualitative methodology. Revista de Metodología de Ciencias Sociales, 4, 165-190.

Cole, R. 1998. The importance of relationships to the availability of credit. Journal of Banking and Finance, 22, 959-977.

Cuena, C.M. 2017. Positive creditworthiness information sharing and credit market functioning. Journal for the Analysis of Law, 3, 1-66.

Dapena, J., Dapena, J. 2003. Information systems in SMEs and access to credit in contexts of information asymmetry. Serie Documentos de Trabajo, Universidad del CEMA: Área: negocios finanzas, 252. Buenos Aires: Universidad del CEMA.

De Bodt, E., Lobez, F., Statnik, J.C. 2005. Credit rationing, customer relationship and the number of banks: An empirical analysis. European Financial Management, 11(2), 195-228.

Degryse, H., Ongena, S. 2005. Distance, lending relationships, and competition. Journal of Finance, 60(1), 231-266.

Degryse, H., Van Cayseele, P. 2000. Relationship lending within a bank-based system: Evidence from European small business data. Journal of Financial Intermediation, 9(1), 90-109.

Diamond, D.W. 1984. Financial intermediation and delegated monitorin. Review of Economics Studies, 51(3), 393-414.

Díaz, A., Gil de San Vicente, I., Murciego, A., Sisti, E., Vivanco, D. 2016. Economicfinancial report on Basque companies. Orkestra. Basque Competitiveness Institute 2016/20.

Elsas, R., Krahnen, J.P. 1998. Is relationship lending special? Evidence from credit-file data in Germany. Journal of Banking and Finance, 22(10-11), 1283-1316.

Fernando, C., Chakraborty, A., Mallick, R. 2002. The importance of being known: Relationship banking and credit limits. Economics Working Paper Archive EconWPA (0209007), 1-28, Cambridge.

García Valdés, M., Suárez Marín, M. 2013. The Delphi method for expert consultation in scientific research. Revista Cubana de Salud Pública 39(2), 253-267. 
Getler, M., Hubbard, G. 1988. Financial factors in business fluctuations. Financial Market Volatility. Federal Reserve Bank of Kansas City.

Giner, Y. 2005. Determinants of rationing in the bank credit market: An empirical study in Andalucía. Doctoral thesis. Cádiz: University of Cádiz.

Gómez Fernández-Aguado, P., Partal Ureña, A. 2010. Gestión y control del riesgo de crédito en la banca. Madrid: Delta Publicaciones.

González, M., Idrobo, J.D., Taborda, R. 2019. Family firms and financial performance: a meta-regression analysis. Academia Revista Latinoamericana de Administración, 32(3), 345-372.

Gupta, U.G., Clarke, R.E. 1996. Theory and applications of the Delphi technique: a bibliography (1975-1994). Technological Forecasting \& Social Change, 53(2), 183211.

Hand, D., Henley, W. 1997. Statistical Classification Methods in Consumer Credit Scoring: a Review. Royal Statistical Society, 523-541.

Hanley, A., O'Donohoe, S. 2009. Relationship banking within the Irish SME sector and is implication, Working Papers, 1553, September, Kiel Institute for the World Economy, Kiel, 1-24.

Harhoff, D., Körting, T. 1998. Lending relationships in Germany. Empirical evidence from survey data. Journal of Banking and Finance, 22(10-11), 1317-1353.

Hernández, G. 2004. Relaciones bancarias: factores explicativos y efecto sobre la deuda de la PYME. Doctoral Thesis, Universidad Politécnica de Cartagena, MIMEO.

Hernández, G., Martínez, P. 2005. Incidencia del número de relaciones bancarias en el endeudamiento de la Pyme y sus determinantes. Revista Española de Financiación y Contabilidad, 34(124), January-March, 13-45.

Hernández, G., Martínez, P. 2006. Efecto de las relaciones bancarias sobre la deuda de las PYME. Revista Europea de Dirección y Economía de la Empresa, 15(3), 9-26.

Hernández, G., Martínez, P. 2010. Relationship lending and SME financing in the continental European bank-based system. Small Business Economics, 34, 465-482.

Illueca, M., Maudos, J. 2006. Coste de la financiación empresarial, banca relacional y competencia bancaria: evidencia del caso español. In: Pérez, F. ed. Relational banking and social capital in Spain. Competition and trust. BBVA Foundation, 167208.

Landeta, J. 1999. The Delphi method. A forecasting technique for uncertainty. Ariel.

Landeta, J., Barrutia, J., Lertxundi, A. 2011. Hybrid Delphi: a methodology to facilitate contribution from experts in professional contexts Technological Forecasting \& Social Change, 78, 1629-1641.

Larrán, M., García-Borbolla, A., Giner, Y. 2010. Determinants of credit rationing to SMEs: An empirical study in Andalucía. European Research in Management and Business Economics, 16(2), 63-82.

Lehmann, E., Neuberger, D. 2001. Do lending relationships matter? Evidence from bank survey data in Germany. Journal of Economic Behaviour \& Organization, 45(4), 339-359.

Leland, H.E., Pyle, D.H. 1977. Informational asymmetries, financial structure and financial intermediation. Journal of Finance, 32(2), 371-387.

Machauer, A., Weber, M. 2000. Number of bank relationships: An indicator of competition, borrower quality, or just size? Centre for Financial Studies Working Paper 2000(06), 1-24.

Martín Rodríguez, M., Sáez Fernández, F. 2001. Public policies to support SME financing: 
Fundamentals, instrumentation and results. Papeles de Economía Española 89/90, 167-186.

Mendizabal, A. 2012. Banking relationship and credit rationing: the case of Spanish SMEs. https://addi.ehu.es/handle/10810/12301.

Montoriol, J. 2006. Relationship Lending and Small Business Finance: Empirical Analysis of Cost of Capital, Credit Rationing, and Firm Performance. Doctoral Thesis, Economics and Business Department, Universitat Pompeu Fabra, Barcelona.

Myers, S. 1984. The Capital Structure Puzzle. Journal of Finance, 39(3), 575-592.

Myers, S., Majluf, N. 1984. Corporate financing and investment decisions when firms have information investors do not have. Journal of Financial Economics, 13(2), 187-221.

Nakamura, L.I. 1992. Exploring the checking account hypothesis. Journal of Retail Banking, winter, 1992-3, 16-34.

Pastor, S.C. 2017. The standardisation of financial information for SMEs and the selfemployed as a key to accessing financing. Revista de Derecho Bancario y Bursátil, 36(146), 179-205.

Payo Alcázar, I., Pérez Cimarra, P. 2016. Improvements in bank financing for SMEs introduced by Spanish regulations. Cuadernos de Información Económica, 254, 1727.

Pedret Yebra, R., Sagnier Delgado, L., García García, I., Morell Detell, A. 2003. Invertigació de mercats I. Barcelona: UOC.

Petersen, M., Rajan, R. 1994. The benefits of lending relationships: evidence from small business data. Journal of Finance, 49, 3-37.

Petersen, M., Rajan, R. 1995. The Effect of Credit Market Competition on Lending Relationships. Quarterly Journal of Economics, 110(2), 407-443.

Petersen, M., Rajan, R. 2002. Does distance still matter? The information revolution in small business lending. Journal of Finance, 57(6), 2533-2570.

Rajan, R., Zingales, L. 1998. Financial Dependence and Growth. American Economic Review, 88, 559-586.

General Secretariat for Industry and Small and Medium-sized Enterprises. 2020. SME Figures. Data December 2020. Available at: https://estadisticas.ipyme.org/Empresas/Informes/InformesEstadisticos.aspx.

Selva, M.J., Giner, Y. 1999. Incidencia del racionamiento de crédito en la estructura financiera de las Pyme. Revista Europea de Dirección y Economía de la Empresa, 8(4), 125-134.

Tascón Fernández, M., Castaño Gutierrez, F. 2009. Predicting business failure: A review. XV AECA Congress. Valladolid: AECA.

Tobin, J. 1987. Financial intermediaries. In: Eatwell, J., Milgate, M., Newman, P. (eds.): The New Palgrave: A Dictionary of Economics. London, Macmillan.

UNACC. 2015. Banca Cooperativa. Revista de la Unión Nacional de Cooperativas de Crédito, 62.

Zhao, T., Casu, B., Ferrari, A. 2009. Competition and risk taking incentives in the lending market: An application to Indian banking. Working Paper Series, SSRN.

Ziane, Y. 2004. Number of Banks and Credit Relationships: An Empirical Approach. Economic Review, 55(3), 419-428. 
ANNEXES:

Table 1: Documentation to be submitted

\begin{tabular}{|c|c|c|c|c|c|c|c|c|c|}
\hline & \multicolumn{3}{|c|}{ MEAN } & \multicolumn{3}{|c|}{ DEVIATION } & \multicolumn{3}{|c|}{$\begin{array}{l}25^{\text {th }} \\
\text { PERCENTILES }\end{array}$} \\
\hline & $\mathbf{T}^{*}$ & A* & D* & $\mathbf{T}$ & $\mathbf{A}$ & D & $\mathbf{T}$ & A & D \\
\hline BALANCE SHEET & 5 & 5 & 5 & 0 & 0 & 0 & 5 & 5 & 5 \\
\hline $\begin{array}{lll}\text { PROFIT } & \text { AND } & \text { LOSS } \\
\text { ACCOUNT } & & \\
\end{array}$ & 5 & 5 & 5 & $\mathbf{0}$ & $\mathbf{0}$ & $\mathbf{0}$ & 5 & 5 & 5 \\
\hline CORPORATION TAX & 4.60 & 4.25 & 4.83 & 0.52 & 0.50 & 0.41 & & & 5 \\
\hline VAT SETTLEMENT & 3.70 & 3.25 & & 0.82 & 0.50 & 0.89 & & & 3.25 \\
\hline $\begin{array}{lr}\text { DECLARATION } & \text { OF } \\
\text { TRANSACTIONS } & \text { WITH } \\
\text { THIRD PARTIES } & \end{array}$ & 3.70 & 3.75 & 3.67 & 0.48 & 0.50 & 0.52 & 3.25 & 3.75 & 3.25 \\
\hline AUDIT REPORT & 4.90 & 4.75 & 5 & 0.32 & & $\mathbf{0}$ & 5 & 4.75 & 5 \\
\hline
\end{tabular}

T*: ALL A*: ANALYSTS D*: DIRECTORS

\begin{tabular}{|c|c|c|c|c|c|c|c|c|c|}
\hline \multirow[t]{2}{*}{ Table 2: Non-financial variables } & \multicolumn{3}{|c|}{ MEAN } & \multicolumn{3}{|c|}{ DEVIATION } & \multicolumn{3}{|c|}{$\begin{array}{l}25^{\text {th }} \\
\text { PERCENTILES }\end{array}$} \\
\hline & $\mathbf{T}$ & $\mathbf{A}$ & D & $\mathbf{T}$ & $\mathbf{A}$ & D & $\mathbf{T}$ & $\mathbf{A}$ & D \\
\hline FIRM SIZE & 3.4 & 3 & 3.67 & 1.26 & 1.41 & 1.21 & 3 & 2.5 & 3 \\
\hline LEGAL FORM & 2.3 & 2 & 2.5 & 1.06 & 1.15 & 1.05 & 1.25 & 1 & 2 \\
\hline AGE & 3.8 & 4 & 3.67 & 0.92 & 0.82 & 1.03 & 3.25 & 3.75 & 3.25 \\
\hline SECTOR & 3.5 & 3.5 & 3.5 & 0.85 & 0.58 & 1.05 & 3 & 3 & 3 \\
\hline COMPETITIVE POSITIONING & 3.9 & 3.5 & 4.17 & 0.88 & 1 & 0.75 & 4 & 3.5 & 4 \\
\hline SHAREHOLDER STRUCTURE & 4.1 & 4 & 4.17 & 0.88 & 0.82 & 0.98 & 3.25 & 3.75 & 3.25 \\
\hline $\begin{array}{l}\text { QUALITY MANAGEMENT } \\
\text { TEAM }\end{array}$ & 4.3 & 4 & 4.5 & 0.95 & 1.41 & 0.55 & 4 & 3.5 & 4 \\
\hline $\begin{array}{ll}\text { OBTAINING } & \text { QUALITY } \\
\text { CERTIFICATES } & \\
\end{array}$ & 2.4 & 2 & 2.67 & 0.7 & 0 & 0.82 & 2 & 2 & 2 \\
\hline $\begin{array}{lll}\text { PURPOSE OF } & \text { THE PROJECT } \\
\text { FOR WHICH } & \text { FINANCING IS } \\
\text { REQUESTED } & & \\
\end{array}$ & 4.8 & 5 & 4.67 & 0.42 & 0 & 0.52 & 5 & 5 & 4.25 \\
\hline $\begin{array}{l}\text { GEOGRAPHICAL SCOPE OF } \\
\text { ACTION }\end{array}$ & 3.2 & 3.25 & 3.17 & 0.79 & 0.96 & 0.75 & 3 & 2.75 & 3 \\
\hline STAFF (size. type of contracts. ...) & 3.11 & 3.25 & 3 & 0.78 & 0.96 & 0.71 & 3 & 2.75 & 3 \\
\hline CUSTOMERS / SUPPLIERS & 4 & 3.75 & 4.17 & 0.67 & 0.96 & 0.41 & 4 & 3 & 4 \\
\hline MARKET SHARE & 3.6 & 3.5 & 3.67 & 0.97 & 1 & 1.03 & 3.25 & 3.5 & 3.25 \\
\hline $\begin{array}{lll}\text { INVOLVEMENT } & \text { OF } & \text { THE } \\
\text { OWNERS } & & \\
\end{array}$ & 5 & 5 & 5 & 0 & 0 & 0 & 5 & 5 & 5 \\
\hline
\end{tabular}

Table 3: Relevant aspects of the visits

\begin{tabular}{|l|l|l|l|l|l|l|l|l|l|}
\multicolumn{2}{c|}{ MEAN } & \multicolumn{3}{l}{ DEVIATION } & \multicolumn{2}{l|}{$\begin{array}{l}\mathbf{2 5}^{\text {th }} \\
\text { PERCENTILES }\end{array}$} \\
\cline { 2 - 14 } & T & A & D & T & A & D & T & A & D \\
\hline PREMISES & 3.9 & 3.75 & & 0.88 & 0.96 & 0.89 & 3 & 3 & 3.25 \\
\hline WORKERS & 3.9 & 4 & 3.83 & 0.57 & 0.82 & 0.41 & 4 & 3.75 & 4 \\
\hline OFFICES & 3.2 & 3 & 3.33 & 0.42 & 0 & 0.52 & 3 & 3 & 3 \\
\hline WAREHOUSES-MACHINERY & 4.67 & 5 & 4.5 & 0.58 & & 0.71 & 4.5 & 5 & 4.25 \\
\hline
\end{tabular}

Table 4: Characteristics of the banking relationship 


\begin{tabular}{|c|c|c|c|c|c|c|c|c|c|}
\hline & \multicolumn{3}{|c|}{ MEAN } & \multicolumn{3}{|c|}{ DEVIATION } & \multicolumn{3}{|c|}{$\begin{array}{l}25^{\text {th }} \\
\text { PERCENTILES }\end{array}$} \\
\hline & $\mathbf{T}$ & $\mathbf{A}$ & D & $\mathbf{T}$ & A & D & $\mathbf{T}$ & $\mathbf{A}$ & D \\
\hline BANKING POOL & 4.67 & 5 & 4.4 & 0.5 & 0 & 0.55 & 4 & 5 & 4 \\
\hline $\begin{array}{l}\text { DURATION OF } \\
\text { RELANIONSHIP }\end{array}$ & 3.89 & 4 & 3.8 & 0.78 & 0.82 & 0.84 & 3 & 3.75 & 3 \\
\hline $\begin{array}{lll}\text { NUMBER } & \text { OF } & \text { FINANCIAL } \\
\text { PRODUCTS CONTRACTED }\end{array}$ & 3.67 & 4.25 & 3.2 & 1.22 & 0.50 & 1.48 & 3 & 4 & 3 \\
\hline CREDIT HISTORY & 4.89 & 5 & 4.8 & 0.33 & 0 & 0.45 & 5 & 5 & 5 \\
\hline OVERDRAFTS FREQUENCY & 4.89 & 5 & 4.8 & 0.33 & 0 & 0.45 & 5 & 5 & 5 \\
\hline OVERDRAFTS & 4.33 & 4.5 & 4.2 & 0.71 & 0.58 & 0.84 & 4 & 4 & 4 \\
\hline LEVEL OF TRUST & 4.56 & 4.5 & 4.6 & 0.53 & 0.58 & 0.55 & 4 & 4 & 4 \\
\hline
\end{tabular}

Table 5: Importance of variables

\begin{tabular}{|l|l|l|l|l|l|l|l|l|l|}
\cline { 2 - 11 } \multicolumn{1}{c|}{} & \multicolumn{2}{l|}{ MEAN } & \multicolumn{2}{l|}{ DEVIATION } & \multicolumn{2}{l|}{$\begin{array}{l}\mathbf{2 5}^{\text {th }} \\
\text { PERCENTILES }\end{array}$} \\
\cline { 2 - 11 } \multicolumn{1}{l|}{} & T & A & D & T & A & D & T & A & D \\
\hline QUANTITATIVE VARIABLES & 4.78 & 5 & 4.67 & 0.44 & 0 & 0.52 & 5 & 5 & 4.25 \\
\hline QUALITATIVE VARIABLES & 4 & 3.67 & 4.17 & 0.71 & 0.58 & 0.75 & 4 & 3.5 & 4 \\
\hline $\begin{array}{l}\text { BANK RELATION } \\
\text { CHARACTERISTICS }\end{array}$ & 4.11 & 4.67 & 3.83 & 0.78 & 0.58 & 0.75 & 4 & 4.5 & 3.25 \\
\hline
\end{tabular}

Table 6: Weight assigned

\begin{tabular}{|c|c|c|c|c|c|c|c|c|c|}
\hline \multirow[t]{2}{*}{ (1) } & \multicolumn{3}{|c|}{ MEAN } & \multicolumn{3}{|c|}{ DEVIATION } & \multicolumn{3}{|c|}{$\begin{array}{l}2^{\text {th }} \\
\text { PERCENTILES }\end{array}$} \\
\hline & $\mathbf{T}$ & $\mathbf{A}$ & D & $\mathbf{T}$ & $\mathbf{A}$ & D & $\mathbf{T}$ & $\mathbf{A}$ & D \\
\hline $\begin{array}{l}\text { QUANTITATIVE } \\
\text { VARIABLES }\end{array}$ & 55 & 60 & 52.5 & 16.96 & 10 & 19.94 & 40 & 55 & 40 \\
\hline $\begin{array}{l}\text { QUALITATIVE } \\
\text { VARIABLES }\end{array}$ & 24.44 & 16.67 & 28.33 & 16.09 & 7.64 & 18.35 & 10 & 12.5 & 12.5 \\
\hline $\begin{array}{lc}\text { BANK } & \text { RELATION } \\
\text { CHARACTERISTICS }\end{array}$ & 20.56 & 23.33 & 19.17 & 9.82 & 10.41 & 10.21 & 15 & 17.5 & 11.5 \\
\hline
\end{tabular}

Table 7: Transmission Information

\begin{tabular}{|l|l|l|l|l|l|l|l|l|l|}
\cline { 2 - 12 } \multicolumn{1}{c|}{} & \multicolumn{4}{l}{ MEAN } & \multicolumn{3}{l|}{ DEVIATION } & \multicolumn{2}{l|}{$\begin{array}{l}\mathbf{2 5}^{\text {th }} \\
\text { PERCENTILES }\end{array}$} \\
\cline { 2 - 12 } & T & A & D & T & A & D & T & A & D \\
\hline TRANSPARENCY & 4.8 & 5 & 4.67 & 0.63 & 0 & 0.82 & 5 & 5 & 5 \\
\hline DEMANDING ATTITUDE & 4 & 5 & 3.33 & 0.94 & 0 & 0.52 & 3 & 5 & 3 \\
\hline ORDERLY INFORMATION & 4.6 & 5 & 4.33 & 0.52 & 0 & 0.52 & 4 & 5 & 4 \\
\hline $\begin{array}{l}\text { SUBSTANTIATED } \\
\text { INFORMATION }\end{array}$ & 4.1 & 4.75 & 3.67 & 0.99 & 0.5 & 1.03 & 4 & 4.75 & 3.25 \\
\hline UP-TO-DATE INFORMATION & 4.3 & 5 & 3.83 & 0.95 & 0 & 0.98 & 4 & 5 & 4 \\
\hline
\end{tabular}

